\title{
Recessive Genes for Resistance to Puccinia striiformis f. sp. hordei in Barley
}

\author{
Xianming Chen and Roland F. Line
}

U.S. Department of Agriculture, Agricultural Research Service, Washington State University, Pullman 99164-6430.

Accepted for publication 4 December 1998.

\begin{abstract}
Chen, X. M., and Line, R. F. 1999. Recessive genes for resistance to Puccinia striiformis f. sp. hordei in barley. Phytopathology 89:226-232.

Barley genotypes Abyssinian 14, BBA 2890, Grannelose Zweizeilige, PI 548708, PI 548734, PI 548747, and Stauffers Obersulzer are resistant to all races of Puccinia striiformis f. sp. hordei identified thus far in North America. Astrix, BBA 809, Bigo, Cambrinus, Emir, Heils Franken, Hiproly, I5, Mazurka, Trumpf, and Varunda have specific resistance to certain races, whereas Topper and Steptoe are susceptible to all races. Seedlings of parents and $\mathrm{F}_{1}, \mathrm{~F}_{2}$, and $\mathrm{F}_{3}$ progeny from crosses of resistant genotypes with Topper and Steptoe were tested for resistance to North American P. striiformis f. sp. hordei races PSH-1, PSH-4, PSH-10, PSH13, and PSH-20. When tested with PSH-1, one recessive gene was detected in BBA 809, BBA 2890, Bigo, Hiproly, and Grannelose Zwei-

In tests with PSH-4, one recessive gene was detected in BBA 809, two recessive genes were detected in Trumpf, and two partially recessive genes were detected in Astrix. In tests with PSH-13, one recessive gene was detected in BBA 2890, Grannelose Zweizeilige, I5, and PI 548708 and two recessive genes were detected in Abyssinian 14, Hiproly, PI 548734, and PI 548747. In tests with PSH-20, one recessive gene was detected in Bigo and a recessive gene and a dominant gene were detected in Heils Franken. A gene in Cambrinus for resistance to PSH-10 and a gene in Mazurka for resistance to PSH-20 were dominant on the basis of the response of the first seedling leaf but recessive on the basis of the response of the second leaf. Four different types of epistasis were detected. Information on the number of genes, mode of inheritance, and nonallelic gene interactions should be useful in understanding the hostpathogen interaction and in breeding barley for resistance to stripe rust.
\end{abstract} zeilige; two recessive genes were detected in Emir, I5, PI 548708, PI 548734, PI 548747, Varunda, and Astrix; and one dominant gene and one recessive gene were detected in Abyssinian 14 and Stauffers Obersulzer.
Additional keywords: Hordeum vulgare L., race-specific resistance.
Stripe rust of barley (Hordeum vulgare L.), caused by Puccinia striiformis Westend. f. sp. hordei (syn. P. glumarum (J. C. Schmidt) Eriks. \& E. Henn.), was first observed in the Unites States in 1991 at Uvalde, TX (33). Since then, the disease has been detected in other areas of Texas as well as in Oklahoma, New Mexico, Arizona, Colorado, Utah, California, Idaho, Montana, Oregon, and Washington (16). The disease is firmly established in the United States, especially in California and the Pacific Northwest, where the environment is very favorable for its development. Because most cultivars grown in the region are susceptible, the disease has a high potential for causing major losses if not controlled.

The use of resistant cultivars has been the most economical method of controlling rusts on cereals. However, information on the nature and genetics of resistance to stripe rust of barley is limited. Probably the earliest report on the genetics of barley stripe rust resistance was that by Murty (30) in 1942 in India. In that study, stripe rust resistance in the American cultivar Alpha was found to be conditioned by two dominant genes. Genetic studies of stripe rust resistance in nine barley genotypes conducted in India were reported during the 1960s (1-4,20,26,34,37). Eight loci for resistance to different Indian races in three barley genotypes, E.B. 145, E.B. 410, and E.B. 438, were named Psl to Ps8 with multiple alleles at the Ps 1 and Ps3 loci (4). Among 11 resistant alleles at the eight loci, eight were dominant and three were recessive (4). Different types of epistasis, such as duplicate dominant, independent recessive, complementary recessive, and inhibitory genes, were reported (1-4,20,26,37).

Corresponding author: Xianming Chen; E-mail address: xianming@mail.wsu.edu

Publication no. P-1999-0112-02R

This article is in the public domain and not copyrightable. It may be freely reprinted with customary crediting of the source. The American Phytopathological Society, 1999.
In Europe, Nover and Scholz (31) studied resistance in Bigo, Abyssinian 14, BBA 2890, Abed Binder 12, and I5 to the European race 24 of $P$. striiformis ( $P$. striiformis f. sp. hordei) and found that the resistance of all five genotypes was controlled by single recessive genes. Allelism tests suggested that Bigo, Abyssinian 14, and BBA 2890 had resistant alleles at the same locus, which was designated $y r$. A gene in Abed Binder 12 was designated $y r 2$, and a gene in I5 was designated yr3. Johnson (21) reported another gene in cultivars Europa, Cambrinus, and Deba Abed designated $\mathrm{Yr} 4$.

Upadhyay and Prakash (36) studied the stripe rust resistance of barley genotypes to Indian races, including the Indian culture that they considered to be race 24 . They reported that Bigo was susceptible to the Indian culture of race 24 and that Abyssinian 14 had one or more additional genes for resistance. In contrast to the study by Nover and Scholz (31), it is not clear whether the races used in India were $P$. striiformis f. sp. hordei or f. sp. tritici. It is also likely that the Indian race 24 was not the same as the European race 24. Most of the races used in the Indian studies were virulent on wheat genotype Michigan Amber, which is resistant to race 24 in Europe and all PSH races of $P$. strifformis f. sp. hordei detected in the United States $(16,23,35)$

We have reported $31 \mathrm{PSH}$ races of $P$. striiformis $\mathrm{f}$. sp. hordei $(16,23)$ since barley stripe rust was first reported in 1991 in the United States (33), and we assume that there are probably additional races. The first genetic study of barley stripe rust resistance in North America was conducted by Chen et al. (7) at Oregon State University in cooperation with the International Wheat and Maize Research Center (CIMMYT) in Mexico. In that study, the stripe rust response of a doubled haploid population was evaluated in Mexico. Using molecular markers and quantitative trait loci mapping approaches, Chen et al. (7) mapped two quantitative trait loci conferring resistance in an elite six-row spring feed barley to the $\mathrm{M}$ arms of chromosomes 7 and 4 . 
In a previous study (16), we reported that barley genotypes PI 548708, PI 548734, PI 548747, BBA2890, Abyssinian 14, Grannelose Zweizeilige, and Stauffers Obersulzer were resistant to all PSH races of $P$. striiformis $\mathrm{f}$. sp. hordei that have been detected in the United States so far and that Heils Franken, Emir, Astrix, Hiproly, Varunda, Trumpf, Mazurka, Bigo, I5, Cambrinus, and BBA 809 were resistant to some PSH races. Genes for resistance in these genotypes might be useful in breeding for resistance and in understanding host-pathogen interactions.

The objectives of this study were to determine the number of genes for resistance and their mode of inheritance in 18 resistant barley genotypes.

\section{MATERIALS AND METHODS}

The resistant and resistant/susceptible barley genotypes listed in Table 1 were crossed with the susceptible cultivars Topper and Steptoe by using the susceptible cultivars as the male parents. Reciprocal crosses were also made in which Steptoe was the female parent. $F_{2}$ progeny were obtained for all crosses, and $F_{3}$ progeny were obtained for the crosses by using Steptoe as the female parent.

Seedlings of parents and $F_{1}, F_{2}$, and $F_{3}$ progeny were planted, inoculated, and grown under controlled conditions described by Chen and Line $(10,11,13)$. North American races PSH-1, PSH-4, PSH-10, PSH-13, and PSH-20 of P. striiformis f. sp. hordei were used to test the resistance. When possible, five to ten parental seedlings, one to three $\mathrm{F}_{1}$ seedlings, 120 to $180 \mathrm{~F}_{2}$ seedlings, and 89 to $120 \mathrm{~F}_{3}$ lines with 12 to 25 seedlings from each line were tested.

Data on infection types were recorded 18 to 22 days after inoculation. A scale of 0 to 9, as described by Line et al. (24), was used. Infection types 0 to 3 were classified as resistant reactions, 4 to 6 as intermediate, and 7 to 9 as susceptible. Chi-square tests were used to determine the goodness of fit of the segregation ratios. For $\mathrm{F}_{3}$ populations that were tested with two different races, chisquare tests were used to test the hypothesis of independent genes for resistance to each race. If the probability for the hypothesis was less than 0.01 , we concluded that the genes controlling resistance to different races were either the same or linked.

\section{RESULTS}

Infection types of parents and $\mathrm{F}_{1}$ progeny, observed resistant, intermediate, and susceptible $F_{2}$ plants, expected $F_{2}$ segregation ratios, and probabilities of chi-square tests for goodness of fit of the segregation ratios are shown in Tables 2 and 3. Numbers of homozygous resistant, segregating, and homozygous susceptible $\mathrm{F}_{3}$ lines, expected ratios, and probabilities of chi-square tests for goodness of fit of the segregation ratios are shown in Table 4. In most cases, results were identical in the reciprocal crosses with Steptoe and the crosses with Topper, and therefore the pooled data are presented in Table 2. The $\mathrm{F}_{3}$ data agreed with the $\mathrm{F}_{2}$ data. $\mathrm{F}_{1}$ plants from all crosses except the crosses with Astrix tested with PSH-4 had a high infection type (IT 8), which is a susceptible reaction. $\mathrm{F}_{1}$ plants from the crosses with Astrix tested with PSH-4 had an intermediate infection type (IT 5). These results indicated that all cultivars except Astrix had resistance that was controlled by recessive genes.

Single recessive genes for resistance. The $\mathrm{F}_{2}$ populations from crosses of BBA 809, BBA 2890, and Bigo with Topper and Steptoe and of Grannelose Zweizeilige with Steptoe segregated in a 1:3 (resistant/susceptible) ratio (Table 2 ). The $F_{3}$ populations of the four resistant genotypes crossed with Steptoe segregated in a 1:2:1 (homozygous resistant/segregating/homozygous susceptible) ratio (Table 4). These results indicated that BBA 809 had a single recessive gene for resistance to PSH-1 and PSH-4, Bigo had a single recessive gene for resistance to $\mathrm{PSH}-1$ and $\mathrm{PSH}-20$, and BBA 2890 and Grannelose Zweizeilige had single recessive genes for resistance to races PSH-1 and PSH-13 on the basis of the reciprocal crosses with Steptoe. The segregation of the Grannelose Zweizeilige $\times$ Topper cross tested with PSH-1 and PSH-13 best fit a 3:13 ratio, suggesting that Topper had a suppressor gene. Chi-square analyses for independent genes (Table 5) indicated that the genes in BBA 809 controlling resistance to PSH-1 and PSH-4 and the genes in Bigo controlling resistance to PSH-1 and PSH-20 were either the same or linked.

Resistance gene recessive in the second leaf and dominant in the first leaf. When tested with PSH-1 (Table 3), Mazurka had IT 2 on both the first (the bottom) and second leaves and Topper and Steptoe had IT 8 on both the first and second leaves. However, the

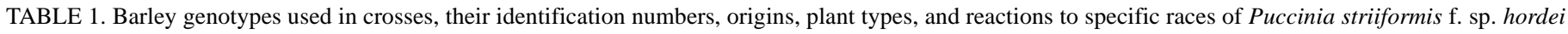
(PSH)

\begin{tabular}{|c|c|c|c|c|c|c|c|c|c|}
\hline \multirow[b]{2}{*}{ Genotype } & \multirow{2}{*}{$\begin{array}{l}\text { Identification } \\
\text { number }^{\mathrm{a}}\end{array}$} & \multirow[b]{2}{*}{ Origin } & \multirow{2}{*}{$\begin{array}{l}\text { Plant } \\
\text { type }^{b}\end{array}$} & \multicolumn{6}{|c|}{ Reaction to $\mathrm{PSH}$ races ${ }^{\mathrm{c}}$} \\
\hline & & & & 1 & 4 & 10 & 13 & 20 & All races \\
\hline Steptoe & CIHO 15229 & United States & 6-row & $\mathrm{S}$ & $\mathrm{S}$ & $\mathrm{S}$ & $\mathrm{S}$ & $\mathrm{S}$ & $\mathrm{S}$ \\
\hline Topper & $\ldots$ & Netherlands & 6-row & $\mathrm{S}$ & $\mathrm{S}$ & $\mathrm{S}$ & $\mathrm{S}$ & $\mathrm{S}$ & $\mathrm{S}$ \\
\hline I5 & PI 268187 & Croatia & 6-row & $\mathrm{R}$ & $\mathrm{R}$ & $\mathrm{R}$ & $\mathrm{R}$ & $\mathrm{R}$ & $\mathrm{R}$ \\
\hline Hor 1428 & PI 548708 & Ethiopia & 2-row & $\mathrm{R}$ & $\mathrm{R}$ & $\mathrm{R}$ & $\mathrm{R}$ & $\mathrm{R}$ & $\mathrm{R}$ \\
\hline Hor 2926 & PI 548734 & Ethiopia & 2-row & $\mathrm{R}$ & $\mathrm{R}$ & $\mathrm{R}$ & $\mathrm{R}$ & $\mathrm{R}$ & $\mathrm{R}$ \\
\hline Hor 3209 & PI 548747 & Ethiopia & 6-row & $\mathrm{R}$ & $\mathrm{R}$ & $\mathrm{R}$ & $\mathrm{R}$ & $\mathrm{R}$ & $\mathrm{R}$ \\
\hline BBA 2890 & BBA 2890 & Germany & 6-row & $\mathrm{R}$ & $\mathrm{R}$ & $\mathrm{R}$ & $\mathrm{R}$ & $\mathrm{R}$ & $\mathrm{R}$ \\
\hline Abyssinian 14 & PI 151789 & Ethiopia & 6-row & $\mathrm{R}$ & $\mathrm{R}$ & $\mathrm{R}$ & $\mathrm{R}$ & $\mathrm{R}$ & $\mathrm{R}$ \\
\hline Grannelose Zweizeilige & PI 548740 & Ethiopia & 2-row & $\mathrm{R}$ & $\mathrm{R}$ & $\mathrm{R}$ & $\mathrm{R}$ & $\mathrm{R}$ & $\mathrm{R}$ \\
\hline Stauffers Obersulzer & PI 467580 & Germany & 2-row & $\mathrm{R}$ & $\mathrm{R}$ & $\mathrm{R}$ & $\mathrm{R}$ & $\mathrm{R}$ & $\mathrm{R}$ \\
\hline Heils Franken & PI 290183 & Germany & 2-row & $\mathrm{S}$ & $\mathrm{S}$ & $\mathrm{R}$ & $\mathrm{S}$ & $\mathrm{R}$ & $\mathrm{R} / \mathrm{S}$ \\
\hline Emir & PI 321787 & Netherlands & 2-row & $\mathrm{R}$ & $\mathrm{R}$ & $\mathrm{S}$ & $\mathrm{S}$ & $\mathrm{S}$ & $\mathrm{R} / \mathrm{S}$ \\
\hline Astrix & PI 339826 & France & 6-row & $\mathrm{R}$ & $\mathrm{R}$ & $\mathrm{R}$ & $\mathrm{R}$ & $\mathrm{R}$ & $\mathrm{R} / \mathrm{S}$ \\
\hline Hiproly & PI 060693 & Egypt & 2-row & $\mathrm{R}$ & $\mathrm{S}$ & $\mathrm{S}$ & $\mathrm{R}$ & $\mathrm{R}$ & $\mathrm{R} / \mathrm{S}$ \\
\hline Varunda & PI 410865 & Netherlands & 2-row & $\mathrm{R}$ & $\mathrm{R}$ & $\mathrm{S}$ & $\mathrm{S}$ & $\mathrm{S}$ & $\mathrm{R} / \mathrm{S}$ \\
\hline Trumpf & PI 548762 & Germany & 2-row & $\mathrm{R}$ & $\mathrm{R}$ & $\mathrm{R}$ & $\mathrm{S}$ & $\mathrm{S}$ & $\mathrm{R} / \mathrm{S}$ \\
\hline Mazurka & PI 399501 & Netherlands & 2-row & $\mathrm{R}$ & $\mathrm{R}$ & $\mathrm{R}$ & $\mathrm{S}$ & $\mathrm{S}$ & $\mathrm{R} / \mathrm{S}$ \\
\hline Bigo & PI 321857 & Netherlands & 6-row & $\mathrm{R}$ & $\mathrm{R}$ & $\mathrm{R}$ & $\mathrm{S}$ & $\mathrm{R}$ & $\mathrm{R} / \mathrm{S}$ \\
\hline Cambrinus & PI 321779 & Netherlands & 2-row & $\mathrm{S}$ & $\mathrm{S}$ & $\mathrm{R}$ & $\mathrm{S}$ & $\mathrm{S}$ & $\mathrm{R} / \mathrm{S}$ \\
\hline BBA 809 & BBA 0809 & Germany & 6-row & $\mathrm{R}$ & $\mathrm{R}$ & $\mathrm{S}$ & $\mathrm{S}$ & $\mathrm{R}$ & $\mathrm{R} / \mathrm{S}$ \\
\hline
\end{tabular}

a $\mathrm{PI}=$ plant introduction number, and $\mathrm{CIHO}=$ cultivar identification number of Hordeum.

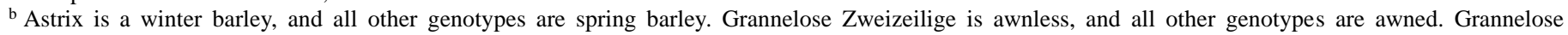

Zweizeilige and Hiproly are hull-less, and all other genotypes are covered.

${ }^{c} \mathrm{~S}=$ susceptible, $\mathrm{R}=$ resistant, and $\mathrm{R} / \mathrm{S}=$ resistant to some of all races detected in the United States and susceptible to other races. 
$\mathrm{F}_{1}$ plants had IT 2 on the first leaves and IT 8 on the second leaves. When the infection type data of the first leaves were analyzed, the $\mathrm{F}_{2}$ populations segregated in a 3:1 (resistant/susceptible) ratio. When the infection type data of the second leaves were analyzed, the $\mathrm{F}_{2}$ populations segregated in a 1:3 (resistant/susceptible) ratio. Thus, the $F_{2}$ plants could be grouped into three classes: first and second leaves resistant, first leaf resistant and second leaf susceptible, and first and second leaves susceptible. A 1:2:1 ratio was obtained for the reciprocal crosses of Mazurka with Steptoe and with Topper. The $\mathrm{F}_{3}$ plants from the Steptoe $\times$ Mazurka cross were also separated into the three classes. Plants that had IT 2 on the first leaf and IT 8 on the second leaf were observed only in the lines that were segregating. Segregation of the $\mathrm{F}_{3}$ population fit a 1:2:1 ratio for resistant, segregating, and susceptible lines (Table 4). Similar results were obtained when the same crosses were tested with PSH-20. The results of the chi-square tests for independent genes (Table 5) indicated that the gene for resistance to PSH-1 and the gene for resistance to PSH-20 were either the same or linked. In tests with PSH-10 (Tables 3 and 4), the results of parents, $F_{1}, F_{2}$, and $\mathrm{F}_{3}$ from crosses of Cambrinus with Topper and Steptoe were similar to those of the Mazurka crosses with Steptoe and Topper tested with PSH-1 and PSH-20. These results indicated that the genes in Mazurka and Cambrinus were expressed dominantly in the first leaf and recessively in the second leaf.
Two independent recessive genes for resistance. When tested with race PSH-1 (Table 2), the $\mathrm{F}_{2}$ populations from crosses of PI 548734, PI 548747, PI 548708, and Astrix with Topper and Steptoe segregated in a 7:9 ratio. The $F_{3}$ lines from the crosses with Steptoe tested with the same race segregated in a 7:8:1 (resistant/ segregating/susceptible) ratio. When tested with race PSH-13, the $\mathrm{F}_{2}$ populations from crosses of PI 548734 and PI 548747 with Topper and Steptoe segregated in a 7:9 ratio, but the $F_{2}$ populations of PI 548708 with Topper and Steptoe segregated in 1:3 (resistant/susceptible) ratio. These results indicated that PI 548734 and PI 548747 each had two independent recessive genes for resistance to PSH-1 and PSH-13 and that PI 548708 had two independent recessive genes for resistance to PSH-1 but only one gene for resistance to PSH-13.

When tested with race PSH-1 (Table 2), $\mathrm{F}_{2}$ segregation of crosses of I5 with Topper and Steptoe with I5 as the female parent fit a ratio of 7:9 (resistant/susceptible) plants, indicating that I5 had two independent recessive genes. The $\mathrm{F}_{2}$ segregation of the cross of I5 with Steptoe in which I5 was used as the male parent best fit a 3:13 (resistant/susceptible) ratio, suggesting a recessive gene and a dominant gene, which were complementary, for resistance. The 1:8:7 $\mathrm{F}_{3}$ ratio obtained from the same cross also showed that resistance to PSH-1 was conditioned by the complementary recessive and dominant genes (Table 4). When tested with race CDL-

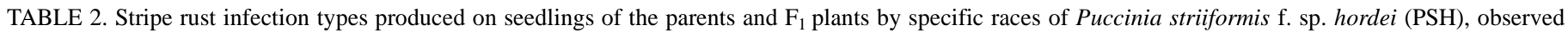

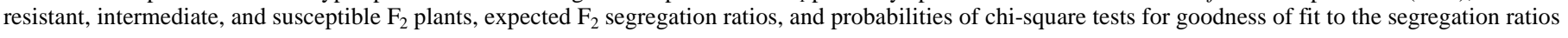

\begin{tabular}{|c|c|c|c|c|c|c|c|c|c|}
\hline \multicolumn{2}{|c|}{ Cross $^{\mathrm{a}}$} & \multirow{2}{*}{$\begin{array}{l}\mathrm{PSH} \\
\text { race }\end{array}$} & \multicolumn{3}{|c|}{ Infection type ${ }^{b}$} & \multicolumn{2}{|c|}{ Observed no. of $F_{2}$ plants $^{c}$} & \multirow{2}{*}{$\begin{array}{c}\text { Expected } \\
\text { ratio }^{\mathrm{d}} \\
(\mathrm{R}: \mathrm{S}) \\
\end{array}$} & \multirow[b]{2}{*}{$P^{\mathrm{e}}$} \\
\hline R-parent & S-parent & & R-p & S-p & $\mathrm{F}_{1}$ & $\mathrm{R}$ & $\mathrm{S}$ & & \\
\hline BBA 809 & Top, Ste(M), Ste(F) & 1 & 2 & 8 & 8 & 124 & 357 & $1: 3$ & 0.69 \\
\hline BBA 809 & Top, Ste(M), Ste(F) & 4 & 1 & 8 & 8 & 111 & 352 & $1: 3$ & 0.61 \\
\hline BBA 2890 & Top, Ste(M), Ste(F) & 1 & 1 & 8 & 8 & 107 & 369 & $1: 3$ & 0.20 \\
\hline BBA 2890 & Top, Ste(M) & 13 & 1 & 8 & 8 & 76 & 248 & $1: 3$ & 0.52 \\
\hline Bigo & Top, Ste(M), Ste(F) & 1 & 1 & 8 & 8 & 106 & 384 & $1: 3$ & 0.09 \\
\hline Bigo & Top, Ste(M), Ste(F) & 20 & 2 & 8 & 8 & 130 & 352 & $1: 3$ & 0.32 \\
\hline G. Zweizeilige & $\operatorname{Ste}(\mathrm{M}), \operatorname{Ste}(\mathrm{F})$ & 1 & 2 & 8 & 8 & 70 & 215 & $1: 3$ & 0.86 \\
\hline G. Zweizeilige & Top & 1 & 2 & 8 & 8 & 24 & 142 & $3: 13$ & 0.16 \\
\hline G. Zweizeilige & Top & 13 & 1 & 8 & 8 & 21 & 144 & $3: 13$ & 0.05 \\
\hline G. Zweizeilige & Ste(M) & 13 & 1 & 8 & 8 & 32 & 101 & $1: 3$ & 0.80 \\
\hline PI 548734 & Top, Ste(M), Ste(F) & 1 & 1 & 8 & 8 & 218 & 269 & $7: 9$ & 0.65 \\
\hline PI 548734 & Top, $\operatorname{Ste}(\mathrm{M})$ & 13 & 1 & 8 & 8 & 137 & 180 & $7: 9$ & 0.85 \\
\hline PI 548747 & Top, Ste(M), Ste(F) & 1 & 1 & 8 & 8 & 192 & 299 & $7: 9$ & 0.04 \\
\hline PI 548747 & Top, Ste(M) & 13 & 1 & 8 & 8 & 139 & 200 & $7: 9$ & 0.31 \\
\hline PI 548708 & Top, Ste(M), Ste(F) & 1 & 1 & 8 & 8 & 184 & 243 & $7: 9$ & 0.78 \\
\hline PI 548708 & Top, Ste(M) & 13 & 1 & 8 & 8 & 97 & 243 & $1: 3$ & 0.13 \\
\hline I5 & Top, Ste(M) & 1 & 2 & 8 & 8 & 132 & 209 & $7: 9$ & 0.06 \\
\hline I5 & $\operatorname{Ste}(F)$ & 1 & 2 & 8 & 8 & 13 & 60 & $3: 13$ & 0.84 \\
\hline I5 & Top, Ste(M) & 13 & 2 & 8 & 8 & 82 & 253 & $1: 3$ & 0.83 \\
\hline Hiproly & Ste(M), Ste(F) & 1 & 2 & 8 & 8 & 60 & 198 & $1: 3$ & 0.52 \\
\hline Hiproly & Top & 1 & 2 & 8 & 8 & 26 & 136 & $3: 13$ & 0.38 \\
\hline Hiproly & Top, Ste(M) & 13 & 1 & 8 & 8 & 21 & 229 & $1: 15$ & 0.16 \\
\hline Abyssinian 14 & Top, Ste(M), Ste(F) & 1 & 2 & 8 & 8 & 100 & 370 & $3: 13$ & 0.16 \\
\hline Abyssinian 14 & Top, Ste(M) & 13 & 0 & 8 & 8 & 23 & 281 & $1: 15$ & 0.34 \\
\hline Heils Franken & Top, Ste(M), Ste(F) & 20 & 2 & 8 & 8 & 54 & 316 & $3: 13$ & 0.04 \\
\hline Emir & Top, $\operatorname{Ste}(M), \operatorname{Ste}(F)$ & 1 & 1 & 8 & 8 & 33 & 421 & $1: 15$ & 0.37 \\
\hline Varunda & Top, Ste(F) & 1 & 2 & 8 & 8 & 25 & 309 & $1: 15$ & 0.35 \\
\hline Varunda & Ste(M) & 1 & 2 & 8 & 8 & 13 & 96 & $3: 13$ & 0.07 \\
\hline Trumpf & Top, Ste(M), Ste(F) & 1 & 2 & 8 & 8 & 38 & 428 & $1: 15$ & 0.09 \\
\hline Trumpf & Top, $\operatorname{Ste}(\mathrm{M}), \operatorname{Ste}(\mathrm{F})$ & 4 & 2 & 8 & 8 & 30 & 353 & $1: 15$ & 0.20 \\
\hline Astrix & Top, Ste(M), Ste(F) & 1 & 3 & 8 & $\ldots f^{f}$ & 184 & 246 & $7: 9$ & 0.69 \\
\hline Astrix & Top, Ste(M), Ste(F) & 4 & 2 & 8 & 5 & $142(105)$ & 188 & $5: 4: 7$ & 0.81 \\
\hline St. Obersulzer & Top, Ste(M) & 1 & 3 & 8 & 8 & 44 & 273 & $3: 13$ & 0.03 \\
\hline St. Obersulzer & Ste $(F)$ & 1 & 3 & 8 & 8 & 13 & 144 & $2: 14$ & 0.11 \\
\hline
\end{tabular}

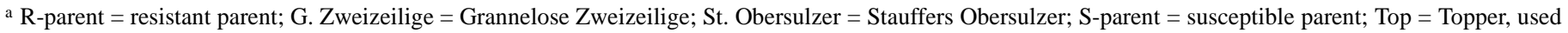
as male parent; and Ste $=$ Steptoe, used as either male parent (M) or female parent $(\mathrm{F})$.

${ }^{b} \mathrm{R}-\mathrm{p}=$ the resistant parent, and $\mathrm{S}-\mathrm{p}=$ the susceptible parent or parents.

${ }^{c} \mathrm{R}=$ resistant, and $\mathrm{S}=$ susceptible. The number of $\mathrm{F}_{2}$ plants with intermediate resistance in crosses involving Astrix tested with race PSH-4 is in parentheses.

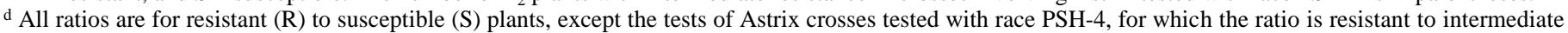
to susceptible plants.

e Probability of chi-square test for goodness of fit.

${ }^{\mathrm{f}}$ Not tested. 


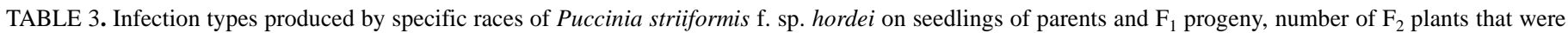

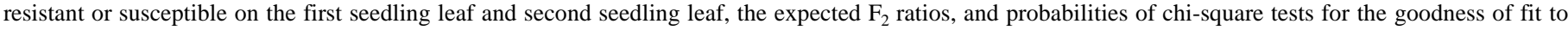
the segregation ratios

\begin{tabular}{|c|c|c|c|c|c|c|c|c|c|c|}
\hline \multirow[b]{2}{*}{ Cross (female $\times$ male) } & \multirow{2}{*}{$\begin{array}{l}\mathrm{PSH} \\
\text { race }\end{array}$} & \multirow{2}{*}{$\begin{array}{l}\text { Leaf } \\
\text { position }\end{array}$} & \multicolumn{3}{|c|}{ Infection type ${ }^{a}$} & \multicolumn{3}{|c|}{ No. of $F_{2}$ plants $^{b}$} & \multicolumn{2}{|c|}{$\mathrm{F}_{2}$ ratio } \\
\hline & & & FP & MP & $\mathrm{F}_{1}$ & $\mathrm{R}$ & $\mathrm{S} / \mathrm{R}$ & $\mathrm{S}$ & $R:(S / R): S$ & $P^{\mathrm{c}}$ \\
\hline Mazurka $\times$ Topper & 1 & $\begin{array}{l}1 \mathrm{st} \\
2 \mathrm{nd} \\
2 \mathrm{nd} / 1 \mathrm{st}\end{array}$ & $\begin{array}{l}2 \\
2 \\
2 / 2\end{array}$ & $\begin{array}{l}8 \\
8 \\
8 / 8\end{array}$ & $\begin{array}{l}2 \\
8 \\
8 / 2\end{array}$ & $\begin{array}{r}123 \\
43 \\
43\end{array}$ & 80 & $\begin{array}{r}45 \\
125 \\
45\end{array}$ & $\begin{array}{l}3: 1 \\
1: 3 \\
1:(2): 1\end{array}$ & $\begin{array}{l}0.59 \\
0.86 \\
0.81\end{array}$ \\
\hline Mazurka $\times$ Steptoe & 1 & $\begin{array}{l}1 \mathrm{st} \\
2 \mathrm{nd} \\
2 \mathrm{nd} / 1 \mathrm{st}\end{array}$ & $\begin{array}{l}2 \\
2 \\
2 / 2\end{array}$ & $\begin{array}{l}8 \\
8 \\
8 / 8\end{array}$ & $\begin{array}{l}2 \\
8 \\
8 / 2\end{array}$ & $\begin{array}{r}125 \\
50 \\
50\end{array}$ & 75 & $\begin{array}{r}37 \\
112 \\
37\end{array}$ & $\begin{array}{l}3: 1 \\
1: 3 \\
1:(2): 1\end{array}$ & $\begin{array}{l}0.53 \\
0.08 \\
0.10\end{array}$ \\
\hline Steptoe $\times$ Mazurka & 1 & $\begin{array}{l}1 \mathrm{st} \\
2 \mathrm{nd} \\
2 \mathrm{nd} / 1 \mathrm{st}\end{array}$ & $\begin{array}{l}8 \\
8 \\
8 / 8\end{array}$ & $\begin{array}{l}2 \\
2 \\
2 / 2\end{array}$ & $\begin{array}{l}2 \\
8 \\
8 / 2\end{array}$ & $\begin{array}{r}114 \\
40 \\
40\end{array}$ & 74 & $\begin{array}{r}38 \\
112 \\
38\end{array}$ & $\begin{array}{l}3: 1 \\
1: 3 \\
1:(2): 1\end{array}$ & $\begin{array}{l}1.00 \\
0.71 \\
0.92\end{array}$ \\
\hline Mazurka $\times$ Topper & 20 & $\begin{array}{l}1 \mathrm{st} \\
2 \mathrm{nd} \\
2 \mathrm{nd} / 1 \mathrm{st}\end{array}$ & $\begin{array}{l}1 \\
2 \\
2 / 1\end{array}$ & $\begin{array}{l}8 \\
8 \\
8 / 8\end{array}$ & $\begin{array}{l}2 \\
8 \\
8 / 2\end{array}$ & $\begin{array}{r}127 \\
41 \\
41\end{array}$ & 86 & $\begin{array}{r}37 \\
123 \\
37\end{array}$ & $\begin{array}{l}3: 1 \\
1: 3 \\
1:(2): 1\end{array}$ & $\begin{array}{l}0.47 \\
1.00 \\
0.75\end{array}$ \\
\hline Mazurka $\times$ Steptoe & 20 & $\begin{array}{l}1 \mathrm{st} \\
2 \mathrm{nd} \\
2 \mathrm{nd} / 1 \mathrm{st}\end{array}$ & $\begin{array}{l}1 \\
2 \\
2 / 1\end{array}$ & $\begin{array}{l}8 \\
8 \\
8 / 8\end{array}$ & $\begin{array}{l}1 \\
8 \\
8 / 1\end{array}$ & $\begin{array}{r}121 \\
43 \\
43\end{array}$ & 78 & $\begin{array}{r}42 \\
120 \\
42\end{array}$ & $\begin{array}{l}3: 1 \\
1: 3 \\
1:(2): 1\end{array}$ & $\begin{array}{l}0.82 \\
0.68 \\
0.86\end{array}$ \\
\hline Steptoe $\times$ Mazurka & 20 & $\begin{array}{l}1 \mathrm{st} \\
2 \mathrm{nd} \\
2 \mathrm{nd} / 1 \mathrm{st}\end{array}$ & $\begin{array}{l}8 \\
8 \\
8 / 8\end{array}$ & $\begin{array}{l}1 \\
2 \\
2 / 1\end{array}$ & $\begin{array}{l}1 \\
8 \\
8 / 1\end{array}$ & $\begin{array}{r}121 \\
41 \\
41\end{array}$ & 80 & $\begin{array}{r}40 \\
120 \\
40\end{array}$ & $\begin{array}{l}3: 1 \\
1: 3 \\
1:(2): 1\end{array}$ & $\begin{array}{l}0.96 \\
0.89 \\
0.99\end{array}$ \\
\hline Cambrinus $\times$ Topper & 10 & $\begin{array}{l}1 \mathrm{st} \\
2 \mathrm{nd} \\
2 \mathrm{nd} / 1 \mathrm{st}\end{array}$ & $\begin{array}{l}2 \\
2 \\
2 / 2\end{array}$ & $\begin{array}{l}8 \\
8 \\
8 / 8\end{array}$ & $\begin{array}{l}2 \\
8 \\
8 / 2\end{array}$ & $\begin{array}{r}132 \\
42 \\
42\end{array}$ & 90 & $\begin{array}{r}38 \\
128 \\
38\end{array}$ & $\begin{array}{l}3: 1 \\
1: 3 \\
1:(2): 1\end{array}$ & $\begin{array}{l}0.43 \\
0.93 \\
0.76\end{array}$ \\
\hline Cambrinus $\times$ Steptoe & 10 & $\begin{array}{l}1 \mathrm{st} \\
2 \mathrm{nd} \\
2 \mathrm{nd} / 1 \mathrm{st}\end{array}$ & $\begin{array}{l}2 \\
2 \\
2 / 2\end{array}$ & $\begin{array}{l}8 \\
8 \\
8 / 8\end{array}$ & $\begin{array}{l}2 \\
8 \\
8 / 2\end{array}$ & $\begin{array}{r}134 \\
46 \\
46\end{array}$ & 88 & $\begin{array}{r}43 \\
131 \\
43\end{array}$ & $\begin{array}{l}3: 1 \\
1: 3 \\
1:(2): 1\end{array}$ & $\begin{array}{l}0.83 \\
0.76 \\
0.95\end{array}$ \\
\hline Steptoe $\times$ Cambrinus & 10 & $\begin{array}{l}1 \mathrm{st} \\
2 \mathrm{nd} \\
2 \mathrm{nd} / 1 \mathrm{st}\end{array}$ & $\begin{array}{l}8 \\
8 \\
8 / 8\end{array}$ & $\begin{array}{l}2 \\
2 \\
2 / 2\end{array}$ & $\begin{array}{l}2 \\
8 \\
8 / 2\end{array}$ & $\begin{array}{r}132 \\
42 \\
42\end{array}$ & 90 & $\begin{array}{r}38 \\
128 \\
38\end{array}$ & $\begin{array}{l}3: 1 \\
1: 3 \\
1:(2): 1\end{array}$ & $\begin{array}{l}0.43 \\
0.93 \\
0.76\end{array}$ \\
\hline
\end{tabular}

a $\mathrm{FP}=$ female parent, and $\mathrm{MP}=$ male parent.

${ }^{b} \mathrm{R}=$ resistant, $\mathrm{S}=$ susceptible, and $\mathrm{S} / \mathrm{R}=$ susceptible reaction on the second leaf and resistant reaction on the first leaf.

c Probability of chi-square test for goodness of fit.

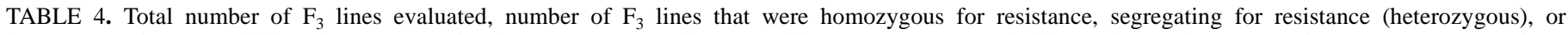

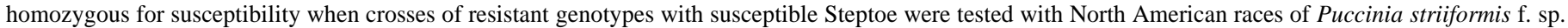
hordei (PSH), expected ratios, and probability of chi-square tests for goodness of fit

\begin{tabular}{|c|c|c|c|c|c|c|c|}
\hline \multirow[b]{2}{*}{ Resistant parent } & \multirow[b]{2}{*}{$\mathrm{PSH}$ race } & \multicolumn{4}{|c|}{ Number of $\mathrm{F}_{3}$ lines } & \multirow{2}{*}{ 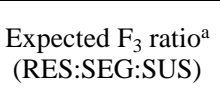 } & \multirow[b]{2}{*}{$P^{\mathrm{b}}$} \\
\hline & & Total & Resistant & Segregating & Susceptible & & \\
\hline BBA 809 & 1 & 120 & 21 & 68 & 31 & $1: 2: 1$ & 0.15 \\
\hline BBA 809 & 4 & 120 & 32 & 61 & 27 & $1: 2: 1$ & 0.80 \\
\hline BBA 2890 & 1 & 89 & 18 & 47 & 24 & $1: 2: 1$ & 0.58 \\
\hline Bigo & 1 & 109 & 37 & 59 & 13 & $1: 2: 1$ & 0.01 \\
\hline Bigo & 20 & 109 & 27 & 63 & 19 & $1: 2: 1$ & 0.15 \\
\hline Grannelose Zweizeilige & 1 & 93 & 23 & 45 & 25 & $1: 2: 1$ & 0.91 \\
\hline Hiproly & 1 & 105 & 21 & 55 & 28 & $1: 2: 1$ & 0.53 \\
\hline Mazurka & 1 & 89 & 18 & 52 & 19 & $1: 2: 1$ & 0.28 \\
\hline Mazurka & 20 & 96 & 26 & 54 & 16 & $1: 2: 1$ & 0.17 \\
\hline Cambrinus & 10 & 112 & 27 & 56 & 29 & $1: 2: 1$ & 0.96 \\
\hline I5 & 1 & 105 & 6 & 51 & 48 & $1: 8: 7$ & 0.91 \\
\hline Abyssinian 14 & 1 & 99 & 7 & 54 & 38 & $1: 8: 7$ & 0.56 \\
\hline Abyssinian 14 & 13 & 100 & 7 & 57 & 36 & $1: 8: 7$ & 0.29 \\
\hline I 5 & 1 & 105 & 6 & 51 & 48 & $1: 8: 7$ & 0.91 \\
\hline Abyssinian 14 & 1 & 99 & 7 & 54 & 38 & $1: 8: 7$ & 0.56 \\
\hline Abyssinian 14 & 13 & 100 & 7 & 57 & 36 & $1: 8: 7$ & 0.29 \\
\hline Emir & 1 & 109 & 6 & 58 & 45 & $1: 8: 7$ & 0.79 \\
\hline Varunda & 1 & 111 & 8 & 61 & 42 & $1: 8: 7$ & 0.45 \\
\hline Trumpf & 1 & 114 & 8 & 62 & 44 & $1: 8: 7$ & 0.54 \\
\hline PI 548708 & 1 & 111 & 47 & 56 & 8 & $7: 8: 1$ & 0.90 \\
\hline PI 548734 & 1 & 100 & 43 & 48 & 9 & $7: 8: 1$ & 0.52 \\
\hline PI 548747 & 1 & 120 & 49 & 60 & 11 & $7: 8: 1$ & 0.39 \\
\hline Astrix & 1 & 106 & 38 & 59 & 9 & $7: 8: 1$ & 0.22 \\
\hline Heils Franken & 20 & 110 & 9 & 65 & 36 & $1: 8: 7$ & 0.06 \\
\hline Stauffers Obersulzer & 1 & 111 & 8 & 56 & 47 & $1: 8: 7$ & 0.90 \\
\hline
\end{tabular}

a RES = homozygous resistant, SEG = segregating, and SUS = susceptible.

b Probability of chi-square test for goodness of fit. 
13 , the $\mathrm{F}_{2}$ populations from crosses of I5 with Topper and Steptoe segregated in a 1:3 (resistant/susceptible) ratio, indicating that I5 had one recessive gene for resistance to race PSH-13 (Table 2).

Two complementary recessive genes for resistance. In crosses of Emir, Varunda, and Trumpf with Topper and Steptoe tested with PSH-1, of Trumpf with Topper and Steptoe tested with PSH-4, and of Hiproly and Abyssinian 14 with Topper and Steptoe tested with $\mathrm{PSH}-13$, the $\mathrm{F}_{2}$ populations segregated in a 1:15 (resistant/susceptible) ratio (Table 2) and the $F_{3}$ populations segregated in a 1:8:7 (homozygous resistant/segregating/homozygous susceptible) ratio (Table 4). The results indicated that the four genotypes each had two complementary recessive genes for resistance to the races with which they were tested. The $\mathrm{F}_{2}$ population of the reciprocal crosses of Hiproly with Steptoe tested with PSH-1 (Table 2) segregated in a 1:3 (resistant/susceptible) ratio, indicating one recessive gene for resistance to PSH-1. The segregation of the Hiproly-Topper cross tested with PSH-1 best fit a 3:13 ratio, indicating that Topper had a suppressor gene. The $F_{2}$ population of Abyssinian 14 segregated in a 3:13 (resistant/susceptible) ratio when inoculated with PSH-1, indicating complementary interaction of a recessive gene and a dominant gene. The $\mathrm{F}_{3}$ data (Table 4) of the female Steptoe crossed with Hiproly (1:2:1) and with Abyssinian 14 (1:8:7) tested with PSH-1 supported the $\mathrm{F}_{2}$ results. Chi-square analysis for independent genes with the $\mathrm{F}_{3}$ data of the Steptoe-Abyssinian 14 cross tested with PSH-1 and PSH-13 (Table 5) indicated that the genes in Abyssinian 14 for resistance to PSH-1 and PSH-13 were not independent.

One recessive gene and one dominant gene for resistance. When the Heils Franken crosses were tested with PSH-20 and the Stauffers Obersulzer crosses and the Varunda $\times$ Steptoe cross were tested with PSH-1, a 3:13 (resistant/susceptible) ratio was obtained for the $F_{2}$ populations (Table 2). When the cross Steptoe $\times$ Stauffers Obersulzer, in which Steptoe was the female parent, was tested with PSH-1, the segregation best fit a 2:14 ratio instead. The $\mathrm{F}_{3}$ lines from crosses of the female Steptoe with Heils Franken and with Stauffers Obersulzer segregated in a 1:8:7 (resistant/ segregating/susceptible) ratio (Table 4). These results indicated that Heils Franken had a recessive gene and a dominant gene for resistance to PSH-4, Stauffers Obersulzer had a recessive gene and a dominant gene for resistance to PSH-1, and the genes in both genotypes were complementary.

TABLE 5. Phenotypic reactions to different races of Puccinia striiformis f. sp. hordei (PSH), observed number of $\mathrm{F}_{3}$ lines, and probabilities of chisquare tests for independent genes in Steptoe $\times$ BBA 809, Steptoe $\times$ Bigo, Steptoe $\times$ Mazurka, and Steptoe $\times$ Abyssinian 14

\begin{tabular}{|c|c|c|c|c|c|}
\hline \multicolumn{2}{|c|}{ Phenotype $^{a}$} & \multicolumn{4}{|c|}{$\begin{array}{l}\text { Observed number of } \mathrm{F}_{3} \text { lines from crosses of } \\
\text { resistant genotypes with Steptoe }\end{array}$} \\
\hline 1 st race & 2nd race & BBA 809 & Bigo & Mazurka & Abyssinian 14 \\
\hline RES & RES & 18 & 22 & 17 & 1 \\
\hline RES & SEG & 3 & 14 & 1 & 6 \\
\hline RES & SUS & 0 & 0 & 0 & 0 \\
\hline SEG & RES & 13 & 5 & 6 & 6 \\
\hline SEG & SEG & 42 & 48 & 41 & 35 \\
\hline SEG & SUS & 13 & 7 & 5 & 13 \\
\hline SUS & RES & 0 & 0 & 0 & 0 \\
\hline SUS & SEG & 16 & 1 & 8 & 16 \\
\hline SUS & SUS & 15 & 12 & 11 & 22 \\
\hline \multirow{2}{*}{\multicolumn{2}{|c|}{$\begin{array}{l}\text { Total } \\
P \text { for independent genes }\end{array}$}} & 120 & 109 & 89 & 99 \\
\hline & & $<0.001$ & $<0.001$ & $<0.001$ & 0.006 \\
\hline \multicolumn{6}{|c|}{$\begin{array}{l}\text { a The first race was PSH- } 1 \text { for all tests, and the second race was PSH- } 4 \text { for } \\
\text { Steptoe } \times \text { BBA } 809 \text {, PSH- } 20 \text { for Steptoe } \times \text { Bigo and Steptoe } \times \text { Mazurka, } \\
\text { and PSH-13 for Steptoe } \times \text { Abyssinian } 14 \text {. RES }=\text { resistant, SEG = segre- } \\
\text { gating, and SUS }=\text { susceptible. } \\
\text { b Steptoe was used as the female parent in all crosses. } \\
\text { c Probability of chi-square test for two independent recessive genes in the } \\
\text { crosses of BBA } 809 \text {, Bigo, and Mazurka. For the Abyssinian } 14 \text { cross, the } \\
\text { chi-square test was for the hypothesis that the two genes (complementary } \\
\text { dominant and recessive) for resistance to race PSH- } 1 \text { are independent of the } \\
\text { two genes (complementary recessive) for resistance to PSH-13. }\end{array}$} \\
\hline
\end{tabular}

Two partially dominant genes for resistance. When tested with race PSH-4 (Table 2), the $\mathrm{F}_{1}$ plants from the reciprocal crosses of Astrix with Steptoe had an intermediate infection type (IT 5), and segregation in $\mathrm{F}_{2}$ populations from crosses of Astrix with Topper and Steptoe fit a 5:4:7 ratio for resistant, intermediate, and susceptible plants. These results suggested that Astrix had two partially dominant genes for resistance to PSH-4 and that the susceptible alleles were epistatic.

\section{DISCUSSION}

Number of barley genes for resistance to stripe rust. Unlike the number of genes reported in wheat for resistance to $P$. striiformis $\mathrm{f}$. sp. tritici $(6,8-15,25,27,28)$, only a few genes in barley have been reported for resistance to $P$. striiformis f. sp. hordei. Eight loci ( $P s 1$ to $P s 8)$, some with multiple resistant alleles, were reported by Indian scientists (4); four genes ( $y r, y r 2, y r 3$, and $Y r 4$ ) were reported by European scientists $(21,31)$; and two unnamed genes were reported by Chen et al. (7) in North America. The genes detected in this study greatly increase the number of known genes for stripe rust resistance in barley.

Of the 18 barley genotypes investigated in this study, three have a single gene and 15 have two or more genes for resistance (Table 6). Data on the reactions to different races of $P$. striiformis $\mathrm{f}$. sp. hordei (16) indicate that there are at least 20 different genes in the resistant genotypes.

Of the 18 genotypes, only five (Abyssinian 14, BBA 2890, Bigo, Cambrinus, and I5) have been previously studied. Nover and Scholz (31) reported that Bigo had a single gene, and Johnson (21) reported that Cambrinus had a single gene. Our data agree with their results. However, Nover and Scholz (31) reported that

TABLE 6. Number of and dominance (D), recessiveness (R), and partial recessiveness $(\mathrm{P})$ of genes in barley genotypes for resistance to $\mathrm{PSH}$ races of Puccinia striiformis f. sp. hordei

\begin{tabular}{|c|c|c|c|}
\hline \multirow[b]{2}{*}{ Genotype } & \multirow[b]{2}{*}{$\begin{array}{l}\mathrm{PSH} \\
\text { race }\end{array}$} & \multicolumn{2}{|c|}{ Inheritance of resistance } \\
\hline & & $\begin{array}{l}\text { Number } \\
\text { of genes }\end{array}$ & $\begin{array}{c}\text { Mode of } \\
\text { inheritance }^{a}\end{array}$ \\
\hline \multirow[t]{2}{*}{ BBA 2890} & 1 & 1 & $1 \mathrm{R}$ \\
\hline & 13 & 1 & $1 \mathrm{R}$ \\
\hline \multirow[t]{2}{*}{ Grannelose Zweizeilige } & 1 & 1 & $1 \mathrm{R}$ \\
\hline & 13 & 1 & $1 \mathrm{R}$ \\
\hline \multirow[t]{2}{*}{ PI 548734} & 1 & 2 & $2 \mathrm{R}$ \\
\hline & 13 & 2 & $2 \mathrm{R}$ \\
\hline \multirow[t]{2}{*}{ PI 548747} & 1 & 2 & $2 \mathrm{R}$ \\
\hline & 13 & 2 & $2 \mathrm{R}$ \\
\hline \multirow[t]{2}{*}{ PI 548708} & 1 & 2 & $2 \mathrm{R}$ \\
\hline & 13 & 1 & $1 \mathrm{R}$ \\
\hline \multirow[t]{2}{*}{ I 5} & 1 & 2 & $2 \mathrm{R}$ \\
\hline & 13 & 1 & $1 \mathrm{R}$ \\
\hline Emir & 1 & 2 & $2 \mathrm{R}$ \\
\hline Varunda & 1 & 2 & $2 \mathrm{R}$ \\
\hline \multirow[t]{2}{*}{ Hiproly } & 1 & 1 & $1 \mathrm{R}$ \\
\hline & 13 & 2 & $2 \mathrm{R}$ \\
\hline \multirow[t]{2}{*}{ Bigo } & 1 & 1 & $1 \mathrm{R}$ \\
\hline & 20 & 1 & $1 \mathrm{R}$ \\
\hline \multirow[t]{2}{*}{ BBA 809} & 1 & 1 & $1 \mathrm{R}$ \\
\hline & 4 & 1 & $1 \mathrm{R}$ \\
\hline \multirow[t]{2}{*}{ Trumpf } & 1 & 2 & $2 \mathrm{R}$ \\
\hline & 4 & 2 & $2 \mathrm{R}$ \\
\hline \multirow[t]{2}{*}{ Astrix } & 1 & 2 & $2 \mathrm{R}$ \\
\hline & 4 & 2 & $2 \mathrm{P}$ \\
\hline St. Obersulzer & 1 & 2 & $1 \mathrm{R}, 1 \mathrm{D}$ \\
\hline \multirow[t]{2}{*}{ Abyssinian 14} & 1 & 2 & $1 \mathrm{R}, 1 \mathrm{D}$ \\
\hline & 13 & 2 & $2 \mathrm{R}$ \\
\hline Heils Franken & 20 & 2 & $1 \mathrm{R}, 1 \mathrm{D}$ \\
\hline Cambrinus & 10 & 1 & $1 \mathrm{R} / \mathrm{D}$ \\
\hline \multirow[t]{2}{*}{ Mazurka } & 1 & 1 & $1 \mathrm{R} / \mathrm{D}$ \\
\hline & 20 & 1 & $1 \mathrm{R} / \mathrm{D}$ \\
\hline
\end{tabular}

a $\mathrm{R}=$ recessive, $\mathrm{D}=$ dominant, $\mathrm{P}=$ partially recessive, and $\mathrm{R} / \mathrm{D}=$ recessive on the second leaf and dominant on the first leaf. 
Abyssinian 14 and I5 each had a single gene, but we detected two genes in each of these genotypes. One of the two genes that we detected in Abyssinian 14 and I5 is probably the same as the gene in Nover and Scholz's report (31).

It is possible to determine whether the same gene or genes, linked genes, or different genes control resistance to different races by testing $\mathrm{F}_{3}$ populations with different races. Because of the large number of crosses, we tested $\mathrm{F}_{3}$ populations of the four resistant genotypes with two races. In these tests, the data suggest that either the same or linked genes confer resistance to both races. Further studies are needed to determine whether they are the same or linked genes. Race PSH-1, which is virulent on only two of the 11 differential genotypes (16), should detect the most resistance genes. This was true for all tests except tests of the progeny from crosses of Hiproly with Topper and Steptoe, which showed one gene for resistance to PSH-1 but two genes for resistance to PSH-13, a race that is virulent on seven of the eleven differential genotypes (16).

Effects of susceptible parents and reciprocal crosses on segregation ratios. In earlier genetic studies of wheat stripe rust resistance, we reported that gene interactions differed depending upon the susceptible parent used in the cross and differed even in some reciprocal crosses $(10,11,14)$. In this study with barley, few such differences were detected. We crossed the 18 genotypes with susceptible Topper and Steptoe using Topper and Steptoe as the male parents and made reciprocal crosses with Steptoe as the female parent. Topper was developed in Europe. Steptoe was developed in Washington State of the United States and has been widely grown in the United States. Both cultivars are susceptible to all identified races of $P$. striiformis $\mathrm{f}$. $\mathrm{sp}$. hordei, which produce IT 8 on Steptoe and IT 9 on Topper. With a few exceptions, results of the crosses with Topper and the reciprocal crosses with Steptoe produced the same results. The reciprocal crosses of Grannelose Zweizeilige with Steptoe tested with both races PSH-1 and PSH13 showed a single recessive gene for resistance, whereas the cross with Topper showed that two genes were involved. The results indicate that Topper has a suppressor gene. This suppressor was also detected in the cross of Hiproly with Topper tested with PSH-1. In the tests with PSH-1, the $\mathrm{F}_{2}$ segregation data from crosses of I5 with Topper and Steptoe when I5 was used as the female parent indicated that I5 has two independent recessive genes. When Steptoe was used as the female parent and tested with the same race, the $F_{2}$ and $F_{3}$ data indicated that one gene was dominant and one gene was recessive and that the interaction was complementary. These results suggest the possibility of maternal effects.

Nonallelic gene interactions. Four types of digenic interactions were detected: two independent recessive genes, two complementary recessive genes, complementary interactions of one recessive gene and one dominant gene, and two partially dominant genes. Two independent recessive genes $\left(7: 9 \mathrm{~F}_{2}\right.$ ratio and 7:8:1 $\mathrm{F}_{3}$ ratio) were detected in crosses of PI 548708, PI 548734, PI 548747, I5, and Astrix with susceptible genotypes. Two complementary recessive genes $\left(1: 15 \mathrm{~F}_{2}\right.$ ratio and 1:8:7 $\mathrm{F}_{3}$ ratio) were detected in crosses of Hiproly, Abyssinian 14, Emir, Varunda, and Trumpf with susceptible genotypes. The complementary interaction of a recessive gene and a dominant gene $\left(3: 13 \mathrm{~F}_{2}\right.$ ratio and 1:8:7 $\mathrm{F}_{3}$ ratio) was detected in crosses of Abyssinian 14, Stauffers Obersulzer, and Heils Franken with susceptible genotypes. The interaction of two partially dominant genes $\left(5: 4: 7 \mathrm{~F}_{2}\right.$ ratio) was detected in crosses of Astrix with susceptible genotypes, in which heterozygous plants produced an intermediate infection type. The first two types of gene interactions have been previously reported $(4,20)$ for barley stripe rust, but the last two types have not. All these types of gene interactions have been reported for wheat stripe rust (10-14).

Recessive genes for resistance. In this study, most of the resistance genes were recessive. Such a large number of recessive genes for resistance has not been reported for any other plantpathogen system. The first report on the inheritance of resistance in wheat to $P$. striiformis f. sp. tritici was in 1905 by Biffen (6), who reported that a recessive gene controlled resistance. Recessive genes for resistance to plant pathogens have been reported in many plant species $(5,17,19,22,29)$. In barley, dominant and recessive genes for stripe rust resistance have been reported in other genotypes $(1-4,20,21,26,30,34,37)$. With findings similar to ours, Nover and Scholz (31) reported recessive genes in crosses of all five barley genotypes in their studies. Our results agree with Nover and Scholz's (31) reports that Bigo, Abyssinian 14, BBA 2890 , and I5 have recessive genes. Our results from the reactions of the first leaves of the Cambrinus crosses agree with Johnson's (21) report that a gene in Cambrinus is dominant. We found that the gene in Cambrinus is dominant in the first leaf and recessive in the second leaf and that a gene in Mazurka is expressed in a similar manner. Changes in gene action from dominant to recessive have been reported in wheat resistance to $P$. striiformis $\mathrm{f}$. $\mathrm{sp}$. tritici $(10-12,15,25,32)$.

Resistance is most often reported to be dominant in studies of the genetics of plant disease resistance. However, in natural plantpathogen systems, recessive resistance may be as frequent as dominant resistance $(5,18)$. The information on the recessive inheritance of the majority of resistance genes detected in this study is useful to breeders in applying special schemes in breeding programs. In breeding for resistance, backcrossing is the major approach for introducing resistance into an otherwise superior cultivar. More complex procedures can be used to incorporate a recessive resistance gene into a commercial cultivar. Selfing before or after each backcross can be used to select lines with a recessive resistance gene. Alternatively, progeny from each backcrossing to the recurrent parent can be test-crossed with the donor parent to determine whether the recessive resistant allele is present. Because many genes identified in this study are of a race-specific type and the durability of resistance in the genotypes resistant to all races has yet to be determined, caution should be taken in using the genes. Pyramiding, multiline, and gene deployment of these genes can be used to obtain durable resistance. The disadvantages of using recessive genes may bring more difficulties for pyramiding several recessive resistance genes into a cultivar or developing multilines. The problem may be overcome by markerassisted selection. With molecular markers, selfing or test-crossing to the donor parent before or after each backcrossing to the recurrent parent should become unnecessary, and therefore incorporation of the recessive genes into new cultivars may be easier and faster. The large number of resistance genes detected in this study provide a good source of resistance. Allelism studies and genome mapping of these genes should be useful for identifying the genes, determining their relationships, locating the genes on chromosomes, and effectively using the genes for controlling stripe rust. The genes that are resistant to all races of $P$. striiformis f. sp. hordei are especially useful because they can provide resistance to a broad range of the pathogen population and may be durable if used in gene pyramiding, multilines, and gene deployment.

\section{LITERATURE CITED}

1. Bahl, P. N., and Backshi, J. S. 1963. Genetics of rust resistance in barley. II. The inheritance of seedling resistance to four races of yellow rust. Indian J. Genet. Plant Breed. 23:150-154.

2. Bakshi, J. S., and Bahl, P. N. 1965. Inheritance of resistance to four races of yellow rust in two varieties of barley. Indian J. Genet. Plant Breed. 25:239-242.

3. Bakshi, J. S., Bahl, P. N., and Kohli, S. P. 1964. Inheritance of seedling resistance to some Indian races of yellow rust in the crosses of rust resistant barley variety E.B. 410. Indian J. Genet. Plant Breed. 24:72-77.

4. Bakshi, J. S., and Luthra, J. K. 1970. Inheritance of resistance to stripe rust (Puccinia striiformis West) in barley. Pages 478-483 in: Proc. Int. Barley Genet. Symp., 2nd.

5. Barrett, J. A. 1985. The gene-for-gene hypothesis: Parable or paradigm. 
Pages 215-225 in: Ecology and Genetics of Host-Parasite Interactions. D. Rollinson and R. M. Anderson, eds. Academic Press, New York.

6. Biffen, R. H. 1905. Mendel's law of inheritance and wheat breeding. J. Agric. Sci. 1:4-48.

7. Chen, F. Q., Prehn, D., Hayes, P. M., Mulrooney, D., Corey, A., and Vivar, H. 1994. Mapping genes for resistance to barley stripe rust (Puccinia striiformis f. sp. hordei). Theor. Appl. Genet. 88:215-219.

8. Chen, X. M., Jones, S. S., and Line, R. F. 1995. Chromosomal location of genes for stripe rust resistance in spring wheat cultivars Compair, Fielder, Lee, and Lemhi and interactions of aneuploid wheats with races of Puccinia striiformis. Phytopathology 85:375-381.

9. Chen, X. M., Jones, S. S., and Line, R. F. 1996. Chromosomal location of genes for resistance to Puccinia striiformis in seven wheat cultivars with resistance genes at the $\mathrm{Yr} 3$ and $\mathrm{Yr} 4$ loci. Phytopathology 86:12281233.

10. Chen, X. M, and Line, R. F. 1992. Inheritance of stripe rust resistance in wheat cultivars used to differentiate races of Puccinia striiformis in North America. Phytopathology 82:633-637.

11. Chen, X. M., and Line, R. F. 1992. Identification of stripe rust resistance genes in wheat genotypes used to differentiate North American races of Puccinia striiformis. Phytopathology 82:1428-1434.

12. Chen, X. M., and Line, R. F. 1992. Genes for resistance to stripe rust in 'Tres' wheat. Crop Sci. 32:692-696.

13. Chen, X. M., and Line, R. F. 1993. Inheritance of stripe rust (yellow rust) resistance in the wheat cultivar Carstens V. Euphytica 71:107-113.

14. Chen, X. M., and Line, R. F. 1993. Inheritance of stripe rust resistance in wheat cultivars postulated to have resistance genes at $\mathrm{Yr} 3$ and $\mathrm{Yr} 4$ loci. Phytopathology 83:382-388.

15. Chen, X. M., Line, R. F., and Jones, S. S. 1995. Chromosomal location of genes for resistance to Puccinia striiformis in winter wheat cultivars Heines VII, Clement, Moro, Tyee, Tres, and Daws. Phytopathology 85: 1362-1367.

16. Chen, X. M., Line, R. F., and Leung, H. 1995. Virulence and polymorphic DNA relationships of Puccinia striiformis $\mathrm{f}$. sp. hordei to other rusts. Phytopathology 85:1335-1342.

17. Day, P. R. 1974. Genetics of Host-Parasite Interaction. Freeman, San Francisco.

18. de Wit, P. J. G. M. 1992. Molecular characterization of gene-for-gene systems in plant-fungus interactions and the application of avirulence genes in control of plant pathogens. Annu. Rev. Phytopathol. 30:391418.

19. Hinze, K., Thompson, R. D., Ritter, E., Salamini, F., and Schulze-Lefert, P. 1991. Restriction fragment length polymorphism-mediated targeting of the ml-o resistance locus in barley (Hordeum vulgare). Proc. Natl. Acad. Sci. USA 88:3691-3695.

20. Jain, K. B. L., and Agrawal, R. K. 1964. Mature plant resistance of barley varieties to Indian races of stripe rust. Indian J. Genet. Plant Breed. 24:203-208.
21. Johnson, R. 1968. Genetics of resistance of barley to stripe rust. (Abstr.) Page 99 in: Int. Congr. Plant Pathol., 1st. University of California Press, Berkeley.

22. Jørgensen, J. H. 1988. Erysiphe graminis, powdery mildew of cereals and grasses. Adv. Plant Pathol. 6:137-157.

23. Line, R. F., and Chen, X. M. 1996. Wheat and barley stripe rust in North America. Pages 101-104 in: Proc. Eur. Mediterr. Cereal Rusts Powdery Mildews Conf., 9th. G. H. J. Kema, R. E. Niks, and R. A. Daamen, eds. Drukkerij Pensen en Looijen B.V., Wageningen, the Netherlands.

24. Line, R. F., Konzak, C. F., and Allan, R. E. 1974. Evaluating resistance to Puccinia striiformis. Pages 125-132 in: Induced Mutations for Disease Resistance in Crop Plants. Proc. Res. Coord. Meet., 1973. International Atomic Energy Agency, Vienna.

25. Lupton F. G. H., and Macer, R. C. F. 1962. Inheritance of resistance to yellow rust (Puccinia glumarum Erikss \& Henn.) in seven varieties of wheat. Trans. Br. Mycol. Soc. 45:21-45.

26. Luthra, J. K. 1966. Inheritance of seedling resistance to races 57 and G of yellow rust in barley. Indian J. Genet. Plant Breed. 26:356-359.

27. McIntosh, R. A. 1983. A catalogue of gene symbols for wheat. Pages 1197-1254 in: Proc. Int. Wheat Genet. Symp., 6th.

28. McIntosh, R. A., Wellings, C. R., and Park, R. F. 1995. Wheat Rusts: Atlas of Resistance Genes. Kluwer Academic, Dordrecht, the Netherlands.

29. Mew, T. W. 1987. Current status and future prospects of research on bacterial blight of rice. Annu. Rev. Plant Pathol. 25:359-382.

30. Murty, S. S. 1942. Segregation and correlated inheritance of rust-resistance and epidermal characters in a barley cross. Indian J. Genet. 2:7375.

31. Nover, I., and Scholz, F. 1969. Genetic studies on the resistance of barley to yellow rust (Puccinia striiformis West.). Theor. Appl. Genet. 39: 150-155.

32. Röbbelen, G., and Sharp, E. L. 1978. Mode of inheritance, interaction, and application of genes conditioning resistance to yellow rust. Verlag Paul Parey, Berlin

33. Roelfs, A. P., Huerta-Espino, J., and Marshall, D. 1992. Barley stripe rust in Texas. Plant Dis. 76:538.

34. Srinivasan, V. K., and Padmanabhan, T. S. 1964. Inheritance of field reaction to yellow rust in barley. Indian J. Genet. Plant Breed. 24:180182.

35. Stubbs, R. W. 1985. Stripe rust. Pages 61-101 in: The Cereal Rusts. Vol 2, Diseases, Distribution, Epidemiology, and Control. A. P. Roelfs and W. R. Bushnell, eds. Academic Press, Orlando, FL.

36. Upadhyay, M. K., and Prakash, S. 1977. Identification of diverse genes conferring resistance to Indian races of stripe rust of barley. Indian J. Genet. Plant Breed. 37:68-72.

37. Upadhyaya, Y. M., Srinivasan, V. K., and Murty, B. N. 1965. Inheritance of yellow rust and leaf blotch resistance and their association with linkage groups in barley. Indian J. Genet. Plant Breed. 25:208-216. 